\title{
Density Functional Theoretical Study on the Proton Migration in Radical Cations of Substituted Cytosine:Guanine Pair
}

\author{
Sungu Hwang ${ }^{1,2, *}$ Yun Hee Jang, ${ }^{3,+}$ Hyun Cho, ${ }^{5}$ and Yong-Jae Lee ${ }^{6}$ \\ ${ }^{1}$ Deparment of Nanomedical Engineering, Pusan National Liniversity, Miryang 627-706, Korea. E-mail: stmguapusan ack \\ -BK21 Kano Fusion Technologv Team, Pusan National Lniversitw, Aingang 627-706, Korea \\ ${ }^{3}$ Department of Materials Science and Engineering. Gwangit Institute of Science and Technolog, Gwangin 500-712, Korea \\ ${ }^{4}$ LEMA, Lniversite François Rabelais, Tours 37200, France \\ ${ }^{5}$ Department of Nanosystem and Nanoprocess Engineering, Pusan National Lniversitv, Hirvang 627-706, Korea \\ 'Department of Horticultural Bioscience, Pusan Kational Chiversity, Airvang 627-706, Korea \\ Received December 10, 2007
}

Key Words : DFT. Proton migration. Radical cations. Cytosine:guanine pair

\begin{abstract}
Guanine or a $G_{\mathrm{n}}$ sequence in duplex DNA has been known a site of the oxidation when the loss of an electron generates a radical cation. This process has extensively investigated due to its relevance to genetic mutation and possible application to molecular electronics. Recently the role of N1 imino proton of the guanine was studied on a DNA oligomer which contains 5-fluorinated cytosine $\left(\mathrm{F}^{\circ} \mathrm{C}\right)$ :guanine pair. The effect of the replacement of hydrogen by fluorine on the proton transfer was monitored.
\end{abstract}

The explanation of this phenomenon and relating reactions was usually done on the basis of solution-phase $\mathrm{p} K_{\mathrm{a}}$ data or computational results on the single nuclear base or $\mathrm{C}: \mathrm{G}$ pair. Density functional theoretical (DFT) calculation on the gasphase $\mathrm{G}: \mathrm{C}$ radical cation pair showed that the structure with a proton attached to guanine $\mathrm{Nl}$ (hereafter $\mathrm{C}(\mathrm{H}) \mathrm{G}^{-}$) is more stable by $1.4 \mathrm{kcal} / \mathrm{mol}$ than that with the proton transferred to cytosine $\left.\left(\mathrm{C}(\mathrm{H})^{-}: \mathrm{G}^{\prime}\right)\right)^{2}$ Ab initio molecular dynamics simulation on $\mathrm{G}: \mathrm{C}$ radical cation pair" showed. however that $\mathrm{C}(\mathrm{H})^{-}: \mathrm{G}^{\cdot}$ is more stable by $3.6 \mathrm{kcal} / \mathrm{mol}$ than $\mathrm{C}(\mathrm{H}) \mathrm{G}^{-}$ when a fully hydrated model is used. indicating that the computation including solvation effect is needed to investigate the proton transfer reaction.

In this work the role of the guanine N1 imino proton in the migration and reaction of radical cation in $\mathrm{F}^{5} \mathrm{C}: \mathrm{G}$ pair $\left(\mathrm{F}^{5} \mathrm{C}:(\mathrm{H}) \mathrm{G}^{-}\right.$) was investigated with a DFT quantum mechanical method in combination with the Poisson-Boltzmann (PB) continuum solvation model. The ease of proton transfer was monitored by calculating the Gibbs energy for both pairs before and after proton transfer.

In Figure 1 depicted were the chemical species that were investigated in this work. All QM calculations used the Jaguar v5.5 quantum chemistry software. ${ }^{4}$ Details for the solvation energy calculation are given elsewhere ${ }^{5-9}$ We optimized solvation parameter of fluorine first. The parameter was optimized to reproduce experimental $\mathrm{p} K_{\mathrm{a}}$ value for heterocyclic aromatic compounds as in our previous work on $\mathrm{Cl}^{5}$. The level of theory of the computation was chosen to be B3LYP/6-31++G**. which was successfully applied to the tautomerism and $\mathrm{p} K_{\mathrm{a}}$ calculations of guanine. isoguanine. oxoguanine and santhine ${ }^{7-\bar{\varphi}} \mathrm{Vdw}$ radii of $\mathrm{H} . \mathrm{O}$. $\mathrm{C}$ and $\mathrm{N}$ were taken from our earlier studies on guanine and its derivatives. $^{7-9}$

The $\mathrm{p} K_{\mathrm{a}}$ value of an acid $\mathrm{HA}$ in aqueous solution is related to the Gibbs free energy change for the deprotonation process expressed by

$$
\mathrm{p} K_{\mathrm{a}}=\Delta G_{\text {dejpata }}^{\mathrm{ij}} / 2.303 R T
$$

where $R$ is the gas constant and $T$ temperature in Kelvin. The standard free energy of deprotonation from one of the deprotonation sites of HA in water. $\Delta G_{\text {ileprot,av. }}^{\dagger}$ is defined as

$$
\Delta G_{\text {deprot.aq }}^{\mathrm{i}}=\Delta G_{\text {aq }}^{\mathrm{i}}\left(\mathrm{A}^{-}\right)+\Delta G_{\mathrm{aq}}^{\mathrm{i}}\left(\mathrm{H}^{-}\right)-\Delta G_{\text {aq }}^{\mathrm{j}}(\mathrm{HA}) \text {. }
$$

The standard free energy' of each species ( $\mathrm{HA}^{-} \mathrm{A}^{-}$. and $\mathrm{H}^{-}$) in water. $\Delta G_{\text {ax. }}^{\text {(1) }}$ can be written by the sum of the gas-phase standard free energy $\Delta G^{\prime}$ and the standard free energy of solvation in water $\Delta G^{\text {') }}$ solv:

$$
\Delta G_{\mathrm{aq}}^{i j}=\Delta G_{\mathrm{g}}^{i j}+\Delta G_{\text {solv. }}^{i}
$$

The standard free energy of each species in the gas phase $\Delta G_{\mathrm{g}}^{(\mathrm{l}}$. is obtained by

$$
\Delta G_{\mathrm{g}}^{\mathrm{i}}=E_{(\mathrm{K}}+\mathrm{ZPE}+\Delta \Delta G_{\mathrm{i})}^{\mathrm{i}} \rightarrow 29 \mathrm{~s} \text {. }
$$

The total energy of the molecule at $0 \mathrm{~K}\left(E_{i \mathrm{~K}}\right)$ was calculated at the optimum geometry from quantum mechanics (QM). Harmonic oscillator-rigid rotor approximation was applied for the calculation: The zero-point energy (ZPE) and the vibrational contribution to Gibbs free energy change from $0 \mathrm{~K}$ to $298 \mathrm{~K}\left(\Delta \Delta G_{i j \rightarrow 298} \mathrm{~K}\right)$ were calculated from frequencies calculated using QM. The translational and rotational free energy contribution was also calculated with the ideal gas approximation.

The accuracy of $\mathrm{p} K_{4}$ calculations depends on two factors: One is the gas phase basicity and the other is the solvation energy. The former can be checked against the gas phase experiment. Therefore we calculated gas phase proton affinity (PA) and gas-phase basicity (GB) at $298 \mathrm{~K}$. which are defined as the enthalpy change and the free energy change. respectively. for the deprotonation process in gas phase.

$$
\begin{aligned}
& \mathrm{PA}=\Delta H_{\mathrm{g}}^{\prime \prime}\left(\mathrm{A}^{-}\right)+\Delta H_{\mathrm{g}}^{(!}\left(\mathrm{H}^{-}\right)-\Delta H_{\mathrm{g}}^{\mathrm{j}}(\mathrm{HA}) \\
& \mathrm{GB}=\Delta G_{\mathrm{g}}^{10}\left(\mathrm{~A}^{-}\right)+\Delta G_{\mathrm{g}}^{10}\left(\mathrm{H}^{-}\right)-\Delta G_{\mathrm{g}}^{(\mathrm{i}}(\mathrm{HA}) .
\end{aligned}
$$

where $\Delta H_{\mathrm{g}}^{\mathrm{l}}\left(\mathrm{H}^{-}\right)=2.5 R T=1.48 \mathrm{kcal} / \mathrm{mol}$ and $\Delta G_{\mathrm{g}}^{\mathrm{O}}\left(\mathrm{H}^{-}\right)=$ 
<smiles></smiles>

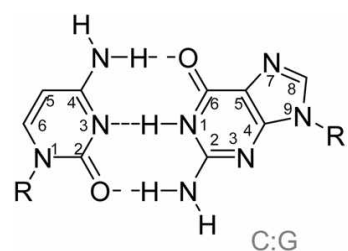<smiles>[R]n1cnc2c([O-])[nH+]c(N)nc21</smiles>

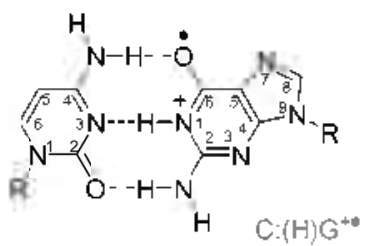

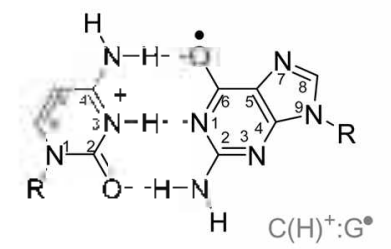

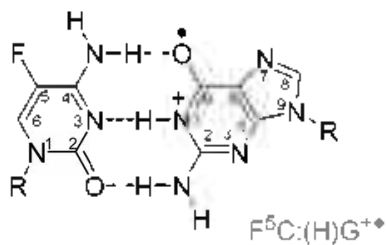

Figure 1. Chemical species used in the present work.

\section{$2.5 R T-T \Delta S^{\dot{j}}=1.48-7.76=-6.28 \mathrm{kcal} / \mathrm{mol}$ at $298 \mathrm{~K}$.}

In Table 2, we summarized the gas phase computational results. which gave excellent agreements with the experimental data. which are comparable to our earlier study on chlorine parameterizations

As discussed earlier. the accuracy of $\mathrm{p} K_{\mathrm{a}}$ calculations depends on both the gas phase basicity and the solvation energy. As shown in Table 2. $\mathrm{p} K_{\mathrm{a}}$ values were in good agreement with the experimental data. which indicates that the vdw parameter for fluorine is well-parameterized.

In the next step. we calculated the Gibbs free energy of

Table 1. van der Waals (vdw) radii used for the solvation energy calculations

\begin{tabular}{cccc}
\hline A tom & & vdw radii $(\mathrm{A})$ & scale factor $^{\sigma}$ \\
\hline $\mathrm{N}$ & $\left(\mathrm{sp}^{2}\right)$ & 1.41 & 0.94 \\
$\mathrm{O}$ & $\left(\mathrm{sp}^{2}\right)$ & 1.48 & 0.94 \\
$\mathrm{C}$ & $\left(\mathrm{sp}^{2}\right)$ & 1.88 & 0.94 \\
$\mathrm{H}$ & $\left(\right.$ attached to $\left.\mathrm{sp}^{2} \mathrm{~N}\right)$ & 1.08 & 0.94 \\
& (attached to $\left.\mathrm{sp}^{2} \mathrm{C}\right)$ & 1.18 & 0.94 \\
$\mathrm{~F}$ & & 1.41 & 0.84 \\
\hline
\end{tabular}

"Scaled from the valued reported in reference ${ }^{\text {l" }}$

Table 2. Proton affinity (PA) and gas phase basicity (GB) and $p K_{a}^{\prime}$ values

\begin{tabular}{|c|c|c|c|c|c|c|}
\hline Bases & $\begin{array}{c}\mathrm{PA} \\
(\mathrm{exp})^{\sigma} \\
\mathrm{kcal} / \mathrm{mol}\end{array}$ & $\begin{array}{c}\mathrm{PA} \\
(\mathrm{calc})^{b} \\
\mathrm{acal} / \mathrm{mo}\end{array}$ & $\begin{array}{c}\mathrm{GB} \\
(\mathrm{exp})^{\sigma} \\
\mathrm{ical} / \mathrm{mol}\end{array}$ & $\begin{array}{c}\mathrm{GB} \\
(\mathrm{calc})^{b} \\
\mathrm{kcal} / \mathrm{mol} \mathrm{l}\end{array}$ & $\begin{array}{l}p K_{4} \\
(e<p)\end{array}$ & $\begin{array}{c}p \mathrm{~K} \\
(\text { colc) }\end{array}$ \\
\hline 2-fluoropy ridine & 211.1 & 212.1 & 203.3 & 204.4 & -0.44 & -1.44 \\
\hline 3-fluoropy ridine & 214.8 & 216.4 & 207.0 & 208.7 & 2.97 & 3.36 \\
\hline
\end{tabular}

Table 3. Gibbs free energy of proton transfer

\begin{tabular}{|c|c|c|}
\hline Bases & $\Delta G_{\text {protort ralister. } \mathrm{g}^{\prime \prime}}$ & $\Delta G_{\text {priston cansister. aq }}$ \\
\hline $\mathrm{C}:(\mathrm{H}) \mathrm{G}^{-\bullet}$ & $1.2 \mathrm{kcal} / \mathrm{mol}$ & $0.0 \mathrm{kcal} / \mathrm{mol}$ \\
\hline $\mathrm{F}^{5} \mathrm{C}:(\mathrm{H}) \mathrm{G}^{-\bullet}$ & $3.5 \mathrm{kcal} / \mathrm{mol}$ & $5.8 \mathrm{kcal} / \mathrm{mol}$ \\
\hline
\end{tabular}

"Gibbs free energy of proton transter in the gas phase, detined by $\Delta G^{\|}$ (after proton transter) $-\Delta G_{\mathrm{z}}^{\prime \prime}$ (betore proton transter). "Gibbs free enengy of proton transfer in aqueous solution. defined by $\Delta G^{n}{ }^{n}$ (after proton transfer) $-\Delta G^{0}$ aq (betore proton transter)

proton transfer $\left(\Delta G_{\text {proton transfer }}\right.$ ) both in the gas-phase and in the aqueous solution. For neutral $\mathrm{G}: \mathrm{C}$ pair. the proton transferred state is not available as expected. The replacement of lydrogen by fluorine at 5 position of $\mathrm{C}$ does not affect the preference. For radical cations. both states before and after proton transfer were calculated to be minima.

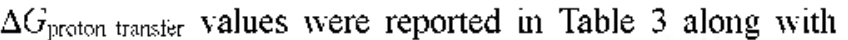
other computational results. The replacement of hydrogen by fluorine makes $\Delta G_{\text {proton tanster }}^{r}$ be more positive in both cases, which results in the inhibition of proton transfer.

In summary. we reported computational results on the proton transfer in $\mathrm{C}: \mathrm{G}$ and $\mathrm{F}^{\mathrm{i}} \mathrm{C}: \mathrm{G}$ radical cations. The effect of the replacement of hydrogen by fluorine on the proton transfer was studied by calculating the Gibbs free energy difference accompanied by the transfer. Our results show that the proton transfer from guanine radical cation to $\mathrm{F}^{\mathrm{C}} \mathrm{C}$ is not favorable. which is consistent with the experimental result.

\section{References}

1. Ghosh. A. K.: Schuster. G. B. J. Am Chem. Soc. 2006. 128. 4172.

2. Li. X.: Cai. Z.: Sevillar, M. D. J. Phys. Chem. B 2001. 105, 10115.

3. Gervasio, F. L.: Laio, A.: Iannuzzi, M.; Parrinello, M. Chem. Eur: J. 2004.10 .4846

4. Jagutar v5.5: Schrodinger Ine.: Portland. Oregon. 2003.

5. Hwang. S.: Jang. Y. H.: Chung. D. S. Bull. Korean Chent. Soc. 2005. 26,585

6. Jang. Y. H.; Sowers. L. C.: Cagin. T.; Goddard II. W. A. J. Phys. Chem \& 2001. 105.274.

7. Jang. Y. H.: Goddard III. W. A.: Noyes. K. T.: Sowers. L. C.: Hwang. S.: Chung. D. S. Chem. Res. Toxicol. 2002. 15. 1023.

8. Jang. Y. H.: Goddard III. W. A.: Noyes. K. T: Sowers. L. C.: Hwang. S.: Chung, D. S. J. Phys. Chem B 2003, 107. 344.

9. Rogstad, K. N.: Jang, Y. H. Sowers, L. C.: Goddard II, W. A. Chem. Res. Toxicol. 2003. 16. 1455.

10. Marten. B.: Kim. K.: Cortis. C.: Friester. R. A.: Murphy. R. B.: Ringnalda. M. N.: Sitkoff. D.: Honig. B. J. Phus. Chem. 1996. 100.11775 .

11. Aue. D. H.; Webb. H. M.; Davidson, W. R.; Toure. P.: Hophins, H. P., Jr.; Moulik, S. P.; Jahagirdar, D. V. J. Am. Chem. Soc. 1991 113,1770 